\title{
A HOME FOR THE IMMORTALS: THE LAYOUT AND DEVELOPMENT OF MEDIEVAL DAOIST MONASTERIES
}

\author{
LIVIA KOHN* \\ (Boston, MA)
}

\begin{abstract}
Monasteries typically have a structure and layout that suits both the spiritual and mundane needs of their communities: a central area that has a place of worship or meditation, a kitchen, refectory, dormitory, guest house, library, and basic work space; an outer layer with more specified workshops, stables and animal hutches, huts for solitary practice, memorial hall, and cemetery; and a third, most outward ring with orchards, fields, mills, and manufacturing sites. Studying the specific layout and organisation of medieval Daoist monasteries, which came to flourish from the sixth century onward, it becomes evident that they follow mainstream Chinese models in their basic layout, imitate Buddhist structures in their buildings and their names, and continue traditional Daoist community centres and meditation retreats. In addition, one can also compare them to ancient Indian and medieval Western institutions, recognising thereby the unique nature of the Daoist monastery. Planned and executed to imitate celestial landscapes and palaces, it served to attract immortals from above and prepare earthly aspirants for a more divine form of life, while also providing spiritual support for the state and a venue of merit-making for aristocratic sponsors.
\end{abstract}

Key words: monastery, community, immortals, architecture, halls, layout, oratory, Buddhism, Daoism.

Monasteries form an important part of the two great world religions, Buddhism and Christianity. In both they serve to create a setting for a life of self-cultivation and religious devotion, a perfect and holy community that yet also maximises opportunities for individual realisation (Kingsley 1987, p. 30). Monasteries can be described as a form of communitas in the sense of Victor Turner (1969), an organisation whose members place themselves on the fringes of ordinary life and onto the threshold to a spiritual or otherworldly attainment. Monastics see themselves as plain and simple; they pursue poverty and equality, practice celibacy, humility, and obedience in an environment of radical heteronomy; they favour silence over speech, anonymity over rank and kinship (see Hillery 1992, p. 51). In most of their goals, as well as their daily activities and behaviour, the recluses set themselves consciously apart, their minds focused on a world greater and holier than that of common humanity.

${ }^{*}$ Livia Kohn, Department of Religion, Boston University, 745 Commonwealth Avenue, Boston, MA 02215, e-mail: 1kohn@bu.edu. 
Yet monasteries are also organisations and as such have to deal with the practicalities of community life and the realities of physical time and space. To incorporate the holy into a practicable routine, monastics create a life that in both its activities and physical setting is significantly different from ordinary patterns. Physical behaviour is highly formalised to the point where "the whole of cenobitic monastic life is choreographed by the rules of the order", every detail being prescribed so that the "heightened consciousness about the motions and thoughts of everyday life becomes itself a transforming mental discipline" (Weckman 1987, p. 38). Physical activity here is a form of "diffuse prayer" (Hillery 1992, p. 157), which raises bodily necessities, such as walking, sitting, sleeping, eating, and washing to a level beyond the world. Along the same lines, time is measured not by ordinary hours but according to sacred services and divided into a set number of periods. In Christian institutions, there are eight offices, from Vigil at 3:30 in the morning to Compline at 7:30 at night (Hillery 1992, p. 155; Burton 1994, pp. 160-161); Buddhist institutions follow the rule of the so-called six periods, which divides the day into equal phases and punctuates it with regular devotions, suspending all ordinary notions of time (Pas 1987 , p. 54, p. 60 ).

Space is another dimension in which monasteries set themselves apart. More than on practical accessibility and topographical realities, the location and layout of monastic institutions are based on the holiness of a given place or design, so that the plan of the monastic establishment - with the main sanctuary and worship hall(s) in the centre and various support divisions around it, such as residences, refectory, and kitchen - reflects the ideal of the given religion combined with the propensities of its setting.

The Daoist religion, as Kristofer Schipper correctly notes, is in essence not monastic but predominantly focuses on lay practice, the harmony of the civil community, and the performance of purification rituals (1984, p. 214). Nevertheless there are two major phases of Daoist monasticism, one in the middle ages (6th-10th centuries), the other beginning in the Song-Yuan dynasties (13th century) and continuing to the present day. While the former reflects the integration of the major medieval Daoist schools under the umbrella of Shangqing 上清 (Highest Clarity) and develops under a generic Buddhist influence, the latter goes back to the imperial support given to official Chan monasteries in the Song, whose organisation the Daoists imitated, especially in the Quanzhen 全真 (Complete Perfection) school. ${ }^{2}$

Daoist monasticism shares the basic characteristics of its Christian and Buddhist counterparts, similarly striving for the establishment of an otherworldly enclave in the ordinary world. However, it rests on a different premise, the ideal of the re-

${ }^{1}$ For a detailed description of medieval Christian monasteries, see Horn-Born 1979; Burton 1994, pp. 131-153; for ancient Buddhist institutions, see Dutt 1962; Buddhist monasteries in China are described in Pripp-Møller 1967; Welch 1967.

${ }^{2}$ For the early phase of Daoist monasticism, see Schipper 1984; Reiter 1983; 1998; Kohn 1997a. On Quanzhen Daoism and its institutions, see Yao 1980; Yoshioka 1979. On the role and organisation of "Chan" monasteries as official designated Buddhist institutions, see Foulk 1987; 1993. 
ligion not being the same as that of either Christianity or Buddhism. That is to say, in Christianity the central focus of monastic practice is the development of spiritual freedom and agape love (Hillery 1992), while in Buddhism it is the attainment of enlightenment and liberation (Prebish 1975). Daoists, in contrast, strive for ascension to the immortals, which is prepared both by physical longevity practices and by spiritual meditations and visualisations. As a result, their monastic institutions serve to create a celestial community on earth and are constructed as a home for the immortals, where celestials come to sojourn and humans can be as immortal as possible within the confines of this world.

The present study focuses on the layout and buildings of medieval Daoist monasteries, using materials found in texts of the Six Dynasties and Tang periods. It begins with a description of the fully developed public monastery as outlined in a text of about 620 C.E., analysing the structure of the Daoist compound in comparison to those of the other great world religions and also in relation to concepts of sacred space and Daoist visions of immortality. A second section discusses - the organisational surroundings of the institution in terms of location and support - the latter including patronage, human resources, and building materials. In both arrangement and conceptualisation this follows the excellent work of Janet Burton on medieval English monasteries (1994). In a third step, the study traces the origins of the Daoist arrangement to imperial palaces, Chinese Buddhist temples, and earlier Daoist community institutions - especially those of the Celestial Masters and Highest Clarity schools - showing the fruitful and unique interaction of the various traditions in the creation of the medieval Daoist monastery. Last, a brief concluding note describes later developments within the Daoist tradition as a combination of the medieval institution with the fully developed Chan monastery of Song China.

\section{The medieval monastery}

Monasteries in general have to provide suitable space for five central activities of the recluses: worshipping, eating, sleeping, working, and administration. Typically all these have separate buildings assigned to them - in a Christian context they are the church, kitchen and refectory, dormitory, cloister, and chapter house (Burton 1994, pp. 141-142). In early Buddhist vihäras, they were the common meeting hall, the kitchen and warehouses, the cells, the walking space, and the shed for special occasions (Prebish 1975, pp. 6-7). Later Buddhist institutions centred around the stüpa as the main focus of worship, which in due course was replaced by a Buddha hall, while the ancient meeting centre became a meditation hall for spiritual practice (Liu 1989, p. 87). In Western scholarly literature, even Buddhist halls for sleeping and eating are often named after their Christian counterparts, while the chapter house is usually called the "administrative wing" 3 and the cloister is defined more specifically depending on the kind of work the monks do. Daoist monasteries, too, follow this

\footnotetext{
${ }^{3}$ Sometimes it is also called the "priory"; see Foulk 1993, p. 196.
} 
pattern, with the sanctuary and scriptural lecture hall in the centre, and various practical localities around them.

In terms of actual layout and construction, although in all the religions the house of worship takes centre place, medieval Christian monasteries tend to be focused on the cloister, the "large square or rectangular piece of ground bounded on one side by the church" (Burton 1994, p. 141). Ideally the church is to the north of the cloister, built on an east-west axis, so that it does not keep the sun from reaching the central courtyard. To the east of the cloister, there are the dormitory (cells after the 13th century) and chapter house, together with a parlour and warming house, where talking is allowed; to the south are kitchen and refectory together with the lavatorium or washing trough, which is often built into the wall; to the west, finally, are storage facilities under the office of the cellarer together with housing for lay brothers and a separate apartment for the abbot (Burton 1994, pp. 142-144).

Ancient Buddhist vihäras, as discovered in archaeological excavations from Taxila (Gandhara) and Sanchi (Madhya Pradesh), followed a similar structure, the central area being an open courtyard, around which the cells of the monks were placed. To the West of this courtyard were the kitchen, refectory, storage areas, and meeting hall (Dutt 1962, pp. 211-213). Later, when worship was added to the monks' central activity of meditation, a stupa was placed in the centre of the courtyard, where it could be easily circumambulated, to be in its turn replaced by a formal Buddha statue and eventually hall (Dutt 1962, p. 214).

In China, the layout of religious institutions, whether Confucian, Daoist, or Buddhist, follows a different architectural plan, one that is adopted from imperial city planning and the construction of royal palaces. To begin, the entire compound is laid out on a north-south axis, with the approach coming from the south and the more sacred halls being further to the north (Liu 1989, p. 28). This goes back to the imperial tradition of the emperor facing south, the direction of yang, as he governs the world (Boyd 1962, p. 70). Three models can be distinguished here: one has the main hall in the centre of the major axis, with other halls located to its front and back, and support facilities arranged lengthwise along its sides; ${ }^{4}$ another has the main hall in the centre of two intersecting axes and the compound becomes more square in overall structure; the third has the central axis extended to allow for more halls to be placed before and behind it, creating a longitudinal extension (Liu 1989, pp. 28-29).

Monasteries typically follow the first of these models, having several key halls in sequence after a central entrance gate, separated by a number of courtyards and possibly connected by covered walkways. In a typical Daoist or Buddhist compound, there would be a main sanctuary for worship of the Three Pure Ones (Sanqing 三 清) or the Buddha and a lecture hall for sermons, the latter also being open to the laity. A similar service to the lay community is also found in Christian monasteries, which often have a separate section in the monastery church or a chapel in the second floor of the gatehouse (Burton 1994, p. 137, p. 146). More meditatively oriented in-

\footnotetext{
${ }^{4}$ This is the oldest and most dominant model. Even kings of the Shang and Zhou as well as later emperors of China were thereby placed in positions of centrality. See Chang 1976, pp. 51-52; Bilsky 1975, pp. 39-42; Soothill 1952; Zito 1997, pp. 132-144.
} 
stitutions, such as those of the Chan school of Buddhism, might also have a meditation hall, placed behind the sanctuary (Foulk 1993, p. 169). Schools with a strong patriarchal tradition, such as the Daoist Quanzhen lineage, similarly might have a separate hall to the patriarchs on the central axis (Yoshioka 1979, p. 250; Liu 1989, p. 133). In addition, Chinese institutions, independent of their affiliation, often also have a smaller sanctuary to the mountain or local god to protect the site.

Having established the main worship places on the central axis, medieval Chinese monasteries then located the utilities buildings on the sides, bath houses, kitchen, and refectory on one, administration, dormitories, and lay quarters on the other. Which side was chosen depended on the natural terrain, the kitchen and bath houses needing the supply of running water, and residential quarters often built closer to the mountainside. Work areas would be found variously, again depending on the topography of the location. Overall the Chinese structure is more open in its layout than the Christian monastery, an impression enhanced by the fact that buildings were in wood, not in stone, and only had one storey instead of two. Typically there was ample greenery between the halls and buildings, creating a sense of open nature rather than an enclosed stone structure that was shielded from the natural world.

It is suitable to think of this central part of the monastery as the inner circle. Surrounding it were two further levels of monastic habitation: an area that held gatehouses, outhouses, workshops, servants' quarters, guest lodges, and facilities for the sick and dying; and a wider territory that provided agricultural services, including fields, orchards, vegetable gardens, mills, fishponds, pastures, and various other facilities (see Burton 1994, pp. 145-148). The further out one went, the less sacred one was and the more commoners would be part of the monastic establishment. True recluses might not venture further than the middle circle, leaving the management of the farms and gardens to lay brothers and outside tenants. Then again, as in Chan monasteries, physical labour might be seen as part of spiritual practice and take a high priority, even to the exclusion of lay workers.

\section{The Daoist institution}

The medieval Daoist institution follows this overall framework and is described as ideally having about thirty different types of buildings and facilities. ${ }^{5}$ The key source for this information is the Fengdao kejie 奉道科戒 (Rules and Precepts for Worshipping the Dao, DZ 1125) ${ }^{6}$ of the early Tang, which consists of eighteen sections in six scrolls. The first ten sections in three scrolls describe the conceptual framework and concrete conditions of Daoist monastic practice, including also one (sect. 4) on monastic buildings, while the last eight deal with specific rituals, formal ranks, ordination formalities, daily services, and meal ceremonies. Several parts of the text,

\footnotetext{
${ }^{5}$ This holds also true for the large, public teaching monasteries of medieval Buddhism. See Foulk 1993, p. 163.

${ }^{6}$ Texts in the Daoist Canon (Daozang 道藏, abbreviated DZ) are given according to Schipper 1975.
} 
including also the entire section on ritual observances and parts of the one on buildings, were discovered in manuscripts at Dunhuang. ${ }^{7}$ Although the preface ascribes the text to the mid-sixth-century visionary Jin Ming Qizhen 金明七真, most scholars today date it to the early Tang dynasty (see Reiter 1983, pp. 366-367; Kohn 1997a; Ōfuchi 1997).

The section on "Setting up Monasteries" is found in the first scroll of the text. It begins by placing Daoist institutions in a direct connection with "the Three Clarity heavens, the ten continents [of the immortals], and the five sacred mountains" of China (1.12b), asserting that all these locations are ultimately of divine origin. ${ }^{8}$ According to the text, the celestial towers and pavilions are formed from coagulating energy; the palaces and chambers are created from accumulating clouds $(12 b-13 a)$. The perfected residences may emerge from spontaneous transformation or be produced from divine power; they may be embellished over a succession of kalpas or be created in single moment (13a). Examples for such divine residences are the paradises of the immortals, such as Penglai 蓬莱 and Yingzhou 赢洲, and the hanging gardens of Mount Kunlun 崑菕. "There are twelve-storied jade towers and three thousand golden turrets, and other wondrous constructions with ten thousand appellations and a thousand different names - impossible to count them all!" (13a).

These, then, created and inhabited by the celestial immortals of the various heavens, form the model for the construction of monasteries on earth. As the text has it: "People imitate the structures found in the high heavens to set up numinous monasteries over here, creating auspicious places and residences fit for immortals" (13a). The Shangqing daolei shixiang 上清道類事相 (Taoist Affairs of Highest Clarity, DZ 1132) similarly emphasises that the centres for Daoist practice on earth match those in the heavens, imitating places where the gods hold their meetings, undergo their training, and have their residences (1.1b-3a).

The central focus of this divinely inspired compound is the Sanctuary to the Heavenly Worthies (tianzun dian 天尊殿), which can be built in different sizes, of "three, five, seven, nine, eleven, or thirteen bays", one "bay" (jian 簡) being the space between two pillars in a traditional building, about three meters wide (Liu 1989, pp. 27-28). A small local temple might have only three bays, while a major sanctuary would have at least seven. In Western measurements, to give one example, the Foguangsi 佛光寺 on Mt. Wutai 五台山 has seven bays and measures 36.27 meters in length and 20.26 meters in depth (Liu 1989, p. 91). While the size depends on the local circumstances, the sanctuary should "always be surrounded by gardens on all sides", be erected on a solid foundation of tamped earth or stone, con-

${ }^{7}$ All manuscripts related to the Fengdao kejie are reprinted in Ōfuchi 1979, pp. 219-242. P. 2337 (see also Yoshioka 1955, pp. 311-340; Liu 1986) contains ritual observances, while S. 3863 has a part of sect. 4 on monastic buildings. P. 3682 and S. 809 contain sections not found in the canon (see Tonkō kōza 1983, pp. 174-176). A basic translation/summary of the Fengdao kejie is found in Reiter 1998. Translations in this article are my own.

${ }^{8}$ A more extensive presentation of various Daoist buildings as being originally part of the celestial realm of the Dao is found in the Daolei shixiang (DZ 1132; see Reiter 1992). Here a point is made, for example, that seven halls on earth with doors to all four cardinal directions match the twenty-eight lunar mansions in the sky (1.7a). 
structed from high-quality wood, ornamented with gold and jade carvings, painted with murals using cinnabar and green colours, and be covered with a tiled or thatched roof (13b). Carvings might include divine creatures, such as phoenixes and dragons; murals might show celestial scenes, such as clouds and the moon; plants growing should be rich and verdant; and there might also be lotus ponds and flowery [imitation] seas (14a). All parts and surfaces can be richly ornamented.

[On the side of the sanctuary] there may also be golden niches and silver corners, ridges of rosy mist and beams of cloudy designs. There may be sun openings and moon windows, yin gates and yang sliding doors. Above, [the ceiling] may reach out to the vaporous expanse; below, [the floor] may be covered with [patterns of] mysterious mist. (14a)

Immediately in front of the main sanctuary, a flat area has to remain open for the erection of an altar platform (tan 壇), which is set up for special ceremonies and ordinations. Built on a foundation of tamped earth, layered bricks, or piled stones, it consists of a wooden scaffold that usually rises three or five layers up (18a) and symbolises the division of the cosmos in heaven, earth, and humanity. It forms a central vertical axis of communication with the divine (Lagerwey 1987, p. 25; see also Benn 1991). Horizontally, on the same axis as the sanctuary and the altar, Daoist institutions have a Scriptural Lecture Hall (jiangjing tang 講經堂), accessible also to the laity. A lesser hall of teaching reserved for the recluses is called the Law Explanation Building (shuofa yuan 説法院); it should be located to the right or left of the sanctuary (15a).

The terminology for these three types of buildings - dian 殿, tang 堂 and yuan 院 - is distinct and clearly defined. As the text says, " 'sanctuary' [dian] is what we call a residence of the sagely personages, while "hall' [tang] refers to a place lived in and used by people" (14a). Both terms come from ancestor worship and are equally used in the mainstream, Confucian tradition. Yuan, on the other hand, is more of a "garden" in civil use and has acquired the sense of "hermitage" in a Buddhist context. The word is here translated by the neutral term "building" because it designates various separate structures for specific purposes, some of which are more secluded than others. The translation "cloister" for yuan, sometimes used in Buddhist studies (e.g., Foulk 1993, p. 164), should be avoided because the facility intended is a building rather than a courtyard. The rendition "subtemple," on the other hand, is very suitable in a Japanese Buddhist context, where numerous smaller compounds, each inhabited by an abbot and a few monks, populate the area around a central monastic axis. ${ }^{9}$

The central axis in a medieval Daoist compound is not complete without the Scripture Tower (jinglou 經樓) and the Bell Pavilion (zhongge 鍾閣), which not only imitate the holy storage spaces and announcement centres of the celestials above (see Daolei shixiang 2.2b-3a), but - similar to the arrangement in a Chinese Buddhist institution (Prip-Møller 1967, p. 9) - should be placed to the left and right be1974.

${ }^{9}$ A classic example for this arrangement would be Daitokuji 大德寺 in Kyoto. See Covell 
fore the main sanctuary. They can be high or low but have to have a fair amount of open space and rather thin walls. In the former this is to allow air to circulate around the scriptures, in the latter it serves to make sure that the "sound of the bell can pass without hindrance" (15a).

Beyond the central axis and ideally on its right (east), the kitchen (zhaichu 齋廚) is found together with the refectory (zhaitang 齋堂), which is described as follows:

Wide doors and open windows should allow easy access, but the main entrance should be covered with a curtain and give to a statue of the Heavenly Worthies. To their right and left, benches and seats, rugs and thick mats should be laid out in accordance with the divine law. Immediately in front of the Heavenly Worthies, moreover, incense burners, flowery pendants, and clean cloths should be placed; to their right and left there should be refectory benches, tables, and mats in proper accordance with the divine law. (15b)

Next, along the same stream of running water used for the kitchen, are the bath house (yutang 浴堂) and the scriptorium (xiejing fang 寫經坊). Baths, as the text insists, must be taken after hard physical labour as well as before any major ceremony. Only when Daoists are "engulfed in the fragrance of a good, clean smell can they perform the services of worship" (16b). The scriptorium, too, uses water, because here the paper for copying the sacred texts is being prepared. For this purpose, there have to be "cloth-beating stones with appropriate clubs, sharp cutting knives, clean benches, tree stumps, and whetting stones" as well as a rack and a hut "to fumigate and spread the scriptures" (16a). All utensils have to be kept clean with cloths and fabrics rinsed in the wash house and must never be allowed to come in contact with ordinary people.

On the other side of the sanctuary and relatively close to it, there should be the Masters' Chambers (shifang 師房) or residence halls of the monks. These fang are defined in the Daolei shixiang as the "chambers where Daoists take in $q i$ 氣”, which match the chambers in the celestial palaces above and must always be kept clean and pure (2.4b-5a). According to the Fengdao kejie, their size and number vary, but in general they were cells rather than dormitories and should be kept "empty and clean, stark and simple" (sect. 10, 3.8b). Permitted furnishings included "a slanted bench, a knee-support, a ritual tablet, a broom, an incense burner, an incense holder, a scripture stand, a kerchief, a chest of wood or bamboo, a seat coverlet, a rope bed, a scripture repository, a lamp stand, various plates and bowls for food, and a water pitcher" (3.9a). This reflects Buddhist usage, according to which monks were originally permitted to have only a bed, seat, and spittoon in their cells (Prebish 1975, p. 5), but later acquired more furniture, including various types of beds and chairs, sitting mats, cushions, rugs, and other elements of comfort (Wijayaratna 1990, pp. 24-27). The same also holds true in Chinese Buddhism, where monks' cells contained a rope-bed, a towel, a clothes-box, a writing knife, and a water pitcher (Prip-Møller 1967, p. 73). 
In addition, the ritual tablet, scripture stand, and incense utensils were part of the standard equipment of Daoist oratories or chambers of tranquillity (jingshi 靜室), the classic meditation place among the Celestial Masters (see Yoshikawa 1987).

Another essential building, which could be erected on any side of the sanctuary but had to be both nearby and relatively isolated, was the Meditation Hall (jingsi yuan 精思院), a facility requiring purity and tranquillity. It should be large enough to allow a group of recluses to practice together, and is open to visiting monks upon close questioning and proper purification. ${ }^{10}$ Next to it, yet not too far from the kitchen, should be a smaller edifice for the preparation of ordinations, the so-called Transmission Building (shoudao yuan 受道院), which might also have its own special altar.

Such are the buildings found in the inner circle of the medieval Daoist monastery. Centred on the north-south central axis, they serve primarily for worship and ceremonies but also include utilities buildings to one side and more quiet places to the other, including residences, a meditation hall, and a building for the preparation of ordinations. There are, at least in the Tang description, no administrative structures, nor any special abbot's quarters. This is similar to early Christian usage, where among the Cistercians the abbot would live in the common dormitory and only Benedictines and Augustinians gradually developed separate apartments for their leader (Burton 1994, p. 144). It is in sharp contrast to later Chan institutions, where the abbot represented the Buddha and for this reason had quarters, the so-called "square yard" (fangzhang 方丈), right along the central axis, sometimes even behind the sanctuary (Foulk 1993, p. 169).

The buildings of the second circle can be divided into two types: one of a more utilitarian nature that included the servants' quarters (jingren fang 淨人坊), the main gate house (menlou 門樓), the stables (leima fang 驛馬坊) and carriage houses (che'niu fang 車牛坊), workshops for fashioning and repairing statues, as well as quarters for both lay (suke fang 俗客坊) and ordained visitors (shifang ke fang 十方客坊; Fengdao kejie 1.17a-18b). ${ }^{11}$ The other is of a more spiritual nature, important but not essential to the key objective of worship and cultivation. Here we have the Ascension Building (shengxia yuan 界遐院) for the dying, and the Incense Building (shaoxiang yuan 燒香院) for funerals and memorial services (17b). This building, as described in the Yaoxiu keyi jielü chao 要修科儀戒律鈔 (Abbreviated Precepts Code of Essential Rules and Observances, DZ 463), a ritual manual of the eighth century, should be located in the Northwest corner of the monastic compound, with its door facing Northwest and be about three bays with five pillars in size. Inside, a central throne should be erected with a statue of a Daoist in

\footnotetext{
${ }^{10}$ This information is supplied in the Qianzhen ke 千真科 (Rules for the Thousand Perfected) as cited in the eighth-century manual Yaоxiu keyi jielü chao (DZ 463), 13.4b. On this text, see Ren and Zhong 1991, p. 344.

${ }^{11}$ The term fang 坊 used here means “quarters" or "workshop". It is also used for the milling facilities (nianwei fang 碾磑坊) and for certain areas of the scriptorium, where practical support work is being done. It is different from the word fang 房 (chamber) used for the Masters' Residences.
} 
the position of "ascension to emptiness". sitting cross-legged in the full lotus posture and his left hand pointing upward towards his destination (15.11a).

In addition, the monastic institution also has a number of special terraces, pavilions, and towers ( $t a i$ 臺, ge 閣, lou 樓), all of which are again in imitation of similar structures in the heavens above. ${ }^{12}$ The latter include Terraces to Search Perfection, to Refine Energy, and to Wait for the Immortals; Pavilions of the Wandering Immortals, of Striding on the Clouds, and of Meeting the Wind; and Towers of the Nine Immortals, of Free and Easy Wandering, and of Tranquil Mindfulness. All these, as the text says, "are dedicated to the ecstatic excursions of the Daoists" (16b). More specifically, the buildings allow practitioners to

soar up in imagination to the highways of the clouds, ascend in true sincerity to the roadways of the stars. They wander in their minds outside of all known bounds and send their eyes to the centre of the universe. ... The location for extraordinary endeavours, these buildings must be separate and thoroughly cut off, yet they should also be easily accessible from the Meditation Hall and the Sanctuary.

In all cases, they must be built so that wind and dew cannot invade them, while clouds and haze meet no obstacle. Also, one must be able to gaze up into the Milky Way from them, to watch the distant course of the stars. On the outside, the buildings should have doors to the four luminant stars; on the sides, windows should be open to the eight winds. This will allow the carriages of the immortals to freely enter and leave, the steeds of the perfected to easily come and go. (16b-17a)

The various terraces and outlaying buildings for ecstatic practice bring home the major difference of the Daoist institution to its Christian and Buddhist counterparts. Here the name guan 觀, lit. "to observe", for the Daoist monastery comes into its own, indicating the direct link Daoists were eager to establish between practitioners on earth and the immortals and celestials above. Star-gazing, the observation of celestial phenomena, and the visualisation of planetary palaces and gods in heavenly realms were central activities of the recluses, and their earthly residences not only imitated the wondrous towers and gardens of the otherworld but their specialised facilities were geared strongly towards the heavens, opening communication in both directions and making specific Daoist practices and attainments possible. ${ }^{13}$

The third circle of the monastic compound, on the other hand, returns again to the more mundane. It includes the herb garden (yaopu 藥围), orchard (guoyuan 果園), and vegetable plots (zaitian 菜田), as well as agricultural estates (zhuang-

${ }^{12}$ In the heavens, terraces are raised edifices that provide room for celestial audiences and always have divine music chiming about them (Daolei shixiang 3.1ab). Pavilions house gods and immortals, sporting vermilion corners and jade turrets (2.2a). Towers are multistoried structures that are used for keeping the life records in jade ledgers and the originals of the sacred scriptures in golden tablets (2.3a).

${ }^{13}$ For the stars and star-related practice in medieval Daoism, see Schafer 1977; Strickmann 1979; Kroll 1985; Robinet 1989. For more on the meaning and derivation of guan for Daoist monastery, see Reiter 1983, p. 365; Schipper 1984, pp. 208-212. 
tian 莊田) and water mills (nianwei 碾磑). The text specifically says that all fruits and flowers to be presented in offerings as well as all vegetables used in meals, with the exception of the five strong-smelling vegetables (wuxin 五辛, garlic, ginger, scallions, leeks, and onions), should be grown locally in the sacred compound (18b19a).

Agricultural estates and water mills are "central to the fixed assets of the institution" (19a). "Fixed assets" translates the technical term changzhu 常住, which was used both in Buddhist and Daoist institutions and could refer either to the permanent residents and staff of the monastery or to its physical establishments (Soothill-Hodous 1937, p. 349). Assets were considered "permanent" in that they were firmly dedicated to the Three Treasures (Buddha, dharma, sangha or Dao, scriptures, and masters); they included statues, halls, and furnishings of the monastery as well as all the lands and agricultural facilities deeded to it. In its narrow sense, changzhu thus indicates "consecrated property"; a wider reading interprets it as all forms of "church property", the entirety of material possessions that made the monastery possible (Gernet 1995, p. 67; see also Twitchett 1956; 1957).

Agricultural estates and water mills were an important part of this extensive church property, especially in the Tang period. In fact, the appearance of this term in the Fengdao kejie has led scholars to date it to the seventh rather than the sixth century. ${ }^{15}$ Agricultural estates can be understood as small villages whose land and income belonged legally to the monastery. They came with serfs who remained hereditarily attached to the monastery and were known as "households held in perpetuity" or "monastery households" (Gernet 1995, p. 149). Water mills were hydraulic facilities used in the milling of various grains which belonged to the monasteries and were rented out to lay millers either for a fixed annual income or for a portion of the grain milled. Both agricultural estates and water mills offered lay followers not only employment but also a chance to accumulate merit and gain a good standing in the Dao. ${ }^{16}$ They served as a major source of income of the institutions, which had considerable expenses in its artworks, regular ceremonies, and feasting of officials (Gernet 1995 , pp. 143-145). ${ }^{17}$

Throughout their compound, whether large or small, rich or poor, medieval Daoist institutions wished to create purity and a sense of celestial peace. This was achieved especially through the cultivation of rich greenery and flowery gardens. As the Fengdao kejie says,

All around the Sanctuary and the various separate buildings and private quarters, greenery should be planted: fruit trees interspersed with blos-

${ }^{14}$ They are also described in Yaoxiu keyi $13.7 \mathrm{~b}-10 \mathrm{~b}$.

${ }^{15}$ See especially Akizuki 1964, pp. 31-33; 1965, pp. 445-448. For more on the use of stone mills in the Tang and in Buddhist institutions, see Ch'en 1973, pp. 151-156.

${ }^{16}$ This point is made in the Zhengyi weiyi jing 正一威儀經 (Scripture of Dignified Observances of Orthodox Unity, DZ 791, 18b), a sixth-century outline of Celestial Masters behavioural codes.

${ }^{17}$ Another, similar industrial estate that formed part of the monastic economy is the establishment of oil presses (Gernet 1995, pp. 150-152). These are not mentioned in the Daoist text. 
soming shrubs, green bamboo next to shimmering ponds. Precious herbs and fragrant flowers should divide the areas and separate the buildings. They shed radiance on the sanctuary and halls, and shade the living quarters in serenity. Their fragrance rises in a numinous wind, their petals shine with the light of wisdom. Time and again, lovely birds come and sing in them, attracting the perfected from on-high. Thus, imitating the jasper terraces above and looking like golden towers below, [the monastery becomes] a place to elevate the heart, a record of [celestial] sojourn [on earth]. (19b)

\section{Location and patronage}

Medieval English monasteries tended to be first urban, later rural. This had to do with their patronage, royal or aristocratic sponsors wishing to have their foundations close at hand and also often securing a burial place for themselves and their families close to the saints honoured in the church. Later monastic institutions, more independent economically, strove for greater solitude and isolation and deliberately sought out empty stretches of country for their establishment, in some cases even intentionally depopulating certain areas to ensure their separation from the common world (Burton 1994, pp. 131-132).

Ancient Buddhist vihäras seem to have occupied a middle ground between town and country, often erected in places where monks could practice in relative quietude yet were also able to interact easily with the laity. The key centres were the holiest sites of the religion, the places of the Buddha's birth, enlightenment, first sermon, and pari-nirvāna, i.e., Lumbinī, Gayā, Sārnāth, and Kushinagara (Dutt 1962, p. 214). Chinese Buddhist institutions followed this model but, like medieval Christian monasteries being dependent on royal or aristocratic support, often were located in the cities. Thus the eastern capital of Luoyang in the sixth century had a large number of flourishing Buddhist centres both within and outside of its walls (see Wang 1984). Only smaller hermitages, lesser temples sponsored by local aristocrats, or residences of famous recluses, such as Huiyuan, were located in the countryside or on sacred mountains, such as Mt. Tiantai or Mt. Lu. In general, the Buddhist institution, however, seems to have striven for a balance between spiritual isolation and lay interaction both in India and in China.

In Daoism, the monastic institution inherited a number of non-monastic forerunners which were located both in cities and the wilderness, including communal meeting halls of the Celestial Masters and the isolated hermitages of would-be immortals. The overall move within the Daoist monastic community, however, was the opposite from that of medieval English monks, i.e., from the isolation of the mountains to the cities, from individual immortality practice to communal and even political services for the world at large.

The earliest Daoist monastery on record was located in the Northern Wei capital. It was the Chongxusi 崇虚寺 (Monastery of Venerating Emptiness), which 
served as the residence of Kou Qianzhi 寇謙之 during the theocracy (see Mather 1979). However, even this was secondary to his major place of spiritual attainment, Mt. Gaosong 高嵩山, the central of the five sacred mountains, where he had revelations of the Dao in 415 and 423. Similarly, Lu Xiujing 陸修靜 (406-477) stayed in a Daoist centre (or "hostel"; guan 館) in the southern capital in the 450s, but his main spiritual home was Mt. Lu 盧山. Daoists, and with them their residences and institutions, descended from the mountains to serve the larger community and always went back to their isolation when no longer needed or desirous of spiritual replenishment.

Both Kou and Lu presumably used small isolated huts or grottoes for their practices on the mountain, following the tradition of the ancient immortality seekers. Shortly after them, however, records indicate the first major centres of Daoist activity being established in a mountain setting, in Louguan in the north and on Maoshan 茅山 in the south. Louguan 樓觀, lit. the "Lookout Tower" or "belvedere," is the first institution to use the word guan 觀, "to observe," as a name for a Daoist centre (Schipper 1984, p. 212). It was located in the foothills of the Zhongnan mountains 終南山, about sixty kilometres southwest of Xi'an. According to legend, it was originally the home of Yin Xi 尹 喜, the Guardian of the Pass and first recipient of the Daode jing 道德經, who had received the estate in reward for official service by King Kang of the Zhou (r. 1078-1052 BC). It was from here that he set out to intercept Laozi on his Westward journey, meeting him on the Hangu Pass, west of Xi' an (see Kohn 1997b). Louguan as a Daoist centre did not come into being until the mid-fifth century, when an alleged descendant of Yin Xi by the name of Yin Tong 尹通 declared it the place where the Daode jing had been transmitted. It flourished after the theocracy came to an end in 448 and soon grew into the major Daoist institution in north China. Texts that remain from the Louguan group indicate that its members observed the five precepts adopted from Buddhism, venerated Laozi and the Daode jing, and honoured Yin Xi as their first patriarch. How far they were a celibate community with a formal organisation that could be truly called "monastic" is not clear.

At the same time, under the guidance of Tao Hongjing 陶弘景 (456-536), the southern mountain of Maoshan (near Nanjing) developed into a major Daoist centre, with several grottoes for individual practices, a number of lesser hostels for minor community ceremonies, and some larger, imperially and princely sponsored institutions for major activities of worship and cultivation (see Bumbacher 1996, p. 494). Thanks to the extensive literary activity of Tao Hongjing, we have some information about the actual practices undertaken on Maoshan, which included both Daoist worship and the establishment of Buddhist shrines (see Funayama 1998), ritual ceremonies to the Dao as well as extensive alchemical experiments (see Strickmann 1979). In addition, we know from the record of the calling and ascension of Zhou Ziliang 周子良 that he did not come to the mountain alone but brought his mother and aunt along, who supported him both physically and spiritually during his sojourn there (see Doub 1971). As Michel Strickmann emphasises, it would, therefore, be "very wrong to think of [the Daoist community at] Mao Shan as a truly 'monastic' 
centre" $(1978$, p. 471), where celibate monks or nuns lived according to a strict rule in a tightly knit religious community.

The same rather haphazard internal organisation probably held true for most Daoist institutions throughout the sixth century, when we find a number of them in various mountains of south China (see Daolei shixiang 1.1a-2a; Bumbacher 1996, p. 493). It is therefore suitable to call these institutions "centres" rather than monasteries, a terminology that is matched by the use of the Chinese word guan 館 ("hostel") in the literature of the time rather than guan 觀 ("observe"), which denotes the Daoist monastery proper.

Such monasteries are not recorded before the Tang dynasty, when the Fengdao kejie specifies the requirements for their establishment and organisation. The text sets out six possible locations, including mountains, cities and suburbs, palaces and side apartment, villages and towns, solitary spots, and crowded areas $(1.13 \mathrm{a}$; Reiter 1998, pp. 76-77). It also emphasises the need for patronage: "In all cases, the institution must be sponsored and protected by an emperor or king, built and maintained with the help of ministers and officials. Sponsoring will allow them to support the ordination of male and female Taoists, to reside in comfort while presenting offerings to the religious community, and thus greatly increase their good karma" (13b).

Imperially sponsored monasteries of the Tang, then, included first of all several major institutions in the capital and on the five sacred mountains of China, ${ }^{18}$ as well as some that were associated with the worship of Laozi, notably Bozhou 毫州 (the god's birthplace) and Louguan (the location of his revelation). In addition, imperial support was given to the main monasteries of Highest Clarity Daoism, on Maoshan, Tiantai shan 天台山, and Wangwu shan 王屋山 near the capital (Schafer 1980), and to lesser mountains if and when they experienced miraculous signs or divine visions that legitimised and spiritualises the dynasty.

In addition to these larger centres, there were numerous smaller hermitages, both in the cities and on mountains, where individual monks or nuns, alone or in small groups, practised the religion. The latter were supported either by their former families or by aristocratic sponsors on whose land they erected their huts (Bumbacher 1996, p. 464; Foulk 1993, p. 164). Some, following the ancient hermit tradition (still alive today; see Porter 1993), also kept themselves alive by eating nuts and herbs, or other foodstuffs the land provided. In some cases, such individually founded places would attract followers and grow into more formal institutions which were then officially recognised and might receive land grants for their support (Bumbacher 1996, p. 465). Begging, unlike in India, was not an option (see Mather 1981), and in this respect Daoist monastics were again in a situation more similar to the monks of medieval England than to their Buddhist counterparts (see Burton 1994, p. 153).

\footnotetext{
${ }^{18}$ The former, renamed gong 宮, "palace”, to indicate their imperial importance, linked Daoist temples with imperial ancestral worship. See Ding 1979. The latter imitated a move by the Sui rulers to place the holiest locations in the country under state-sponsored Buddhist tutelage. See Forte 1992, p. 216.
} 


\section{Resources and the role of the state}

In terms of resources, monasteries needed both human skill and labour for their erection and upkeep and also building and other materials for their establishment. In England, most monastic buildings were designed and built by professionals, abbots and priors exerting an influence at the planning stage but largely staying out of the execution. Typically cathedrals would be built under the guidance of a master mason, who usually remained anonymous. The great institutions needed large contingents of workers. To give an example, Westminster Abbey employed 220 labourers, 56 free masons, 49 marblers, 28 masons, 23 carpenters, 15 polishers, 17 smiths, 14 glaziers, and 4 plumbers, at an enormous expense (Burton 1994, p. 150). Materials for building in the English Middle Ages tended to come from local sources, the monastery being given rights to certain quarries, stretches of woodland, and mineral sources. If necessary, special transport facilities, such as roads or canals, would be created to allow the best construction possible (Burton 1994, p. 152). All in all, the building of a monastic establishment was a major undertaking, available only to people of high rank and outstanding resources.

A similar case is true for monasteries in medieval China, and this certainly explains the large degree of imperial and aristocratic sponsorship. Not only were there numerous halls to be built, but they had to be constructed from the best materials available - always expensive and sometimes hard to find. The bulk of the construction materials was wood, but certain types of wood, such as fragrant sandalwood from the Chen river, were preferred to others. In addition, roofs required tiles and walls had to be mixed from various sands and minerals to make them strong, sturdy, and holy enough for the location intended.

In addition, a set of buildings alone does not make a monastery, but worship requires statues and sets of utensils. Statues had to be fashioned from the best of the best and were to be created only from precious substances. Materials named in the Fengdao kejie include gemstones, such as jade, jasper, carneole, lapis lazuli, and crystal; metals, such as gold, silver, bronze, iron, tin, and pewter; fragrant wood, such as sandalwood from the Chen river; precious fabrics, such as silk, gauze, damask, or other richly embroidered cloth; and other, lesser substances, including clay, hemp, stone, and wood pulp (sect. 5, 2.1b; see Reiter 1988).

Not standing alone, however, the statues had to be placed on altars, to be carved from high-quality wood, and be given thrones to reside on. The Heavenly Worthies, in particular, set up in the central Sanctuary of the institution, had to have a proper high seat, which could come in a number of different artistic forms. These included a thousand-petalled lotus flower, a five-coloured lion, a seven-jewelled golden couch, a nine-layered jade seat, a structure made up of nine crouching dragons, or again one of eight coiled-up snakes (2.5a), making sure that "the Heavenly Worthy, as he manifests physically in accordance with the transformations, comes to reside for the ceremonies performed" (5a).

Similarly the sacred scriptures, the second major requirement of the monastery, could not just be written on any odd paper but had to be created in a fashion 
suitable to their holy status. The Fengdao kejie accordingly describes twelve forms in which the perfect scriptures could be produced: engraved on gold tablets, sealed on silver plaques, chiselled on flat stone, carved in wood or on bamboo, written on silk, in lacquer, gold, or silver, on walls, paper, and on leaves (2.6ab). Most of these materials were precious and costly, and had to be provided in proper quantities - requiring heavy gifts from patrons and ordinands. It is thus not surprising that the two imperial princesses who were ordained as Daoist nuns in 711 furnished staggering amounts of precious metal, silk fabric, incense, and other utensils (Benn 1991, pp. 32-38). These were not extravagances to be squandered among the rich but essential materials necessary for the proper functioning of a monastery - at least of one that was a major teaching and ordination centre.

In addition, the monastery needed skilled labourers to do much of the work, not only in construction but also in the sculpting of statues and carvings, the painting of murals and screens, the making of paper and other necessary materials. These labourers were needed at all stages of the monastic development, more so in the beginning than later on, but wooden buildings and statues tended to decay and disintegrate, necessitating a constant stream of repair work. As the Fengdao kejie says, "The sacred images ... may age over many years or sustain damage through blowing wind and driving rain. If that happens, repair and restore them in good time, not allowing the perfected countenances to break or collapse" (2.5b). Not only the basic materials for building and ornamentation, then, but also the labour to build and maintain them were costly items in the establishment of medieval monasteries.

There were two side effects of this costly nature of the institutions and their engagement of state property. One was the criticism voiced against them in the debates among Buddhists and Daoists, the second the high degree of dependency on state support. Criticism of extravagance and practical uselessness is voiced especially by Daoists, who had fewer institutions and less grandeur and were more willing to do civil service, against their Buddhist competitors. The debates, of course, were primarily political in nature, but the allegations about sizes and costs of monastic establishments were not entirely without foundation.

The most active proponent of this criticism was Fu Yi 傅奕 (555-639), a Daoist representative in the court debates of the early Tang. In his Jiansheng sita sengni yikuo limin shi 減省寺塔僧尼益國利民事 (Memorial on Reducing Buddhist Institutions and Recluses to Enhance the State and Benefit the People; T. 2103, 52.134a-35b), ${ }^{19}$ he harshly criticises Buddhist institutions, claiming that there were 200,000 monks and nuns who did not contribute to the economy but were eating grain and wearing silk, never reproduced or served in the army but were supported entirely out of state coffers - altogether nothing but a liability for the state. His second point focuses on religious buildings, including monasteries, temples, and stūpas, of which there were 84,000 , often executed in fancy styles and with overly rich ornamentation.

\footnotetext{
${ }^{19}$ On this text, see Wright 1951; 1990, pp. 112-123; de Groot 1903, pp. 39-41; Yoshikawa 1984, pp. 535-539; Kohn 1995, p. 181.
} 
He then contrasts this extravagance with the architecture of antiquity, when rulers built simple structures of pounded earth with thatched roofs and no more than ten or so at a time. Then government was in good shape and nature in harmony, unlike today when extravagant expenses for religious institutions ruin the country. To remedy, it would be best to defrock all the recluses, get them to reproduce and work in the fields, while putting their temples and monasteries to excellent use as garrisons for the army or other public facilities (Kohn 1995, pp. 180-184). This, of course, is strongly reminiscent of the actual measures taken by the Communists in the early 1950 s, showing that a deep-seated unease with religious institutions, and especially with state-sponsored and costly ones, has continued to be part of the Chinese religious scene. Still, the justification of spiritual merit and divine legitimation created by the institutions in general carried the day, so that monasteries continued to be founded and supported.

While Fu Yi's criticism is that of a lay Daoist against the extravagance of Buddhist monastic institutions, his arguments hold true equally well for the large statesupported Daoist monasteries. Confucian officials have time and again expressed concerns along the very same lines as presented in his memorial and thus criticised all kinds of reclusive organisations that would distance themselves from the mainstream social standards. Persecutions of religions in traditional China, then, were hardly ever aimed at only one organised or monastic group, but treated Buddhists equally as harshly as Daoists. Daoist monasteries as described in the texts, with their extensive ornamentation and precious substances, laid themselves open to criticism and civil rejection.

The other side effect of the expenses involved in creating and maintaining monasteries was that they were virtually dependent on state support, which also came with a great degree of state control. The state instituted regulations and punishments for ordained recluses, both Buddhist and Daoist, in the early Tang dynasty. They have survived in two sets of sources, a specific code for the clergy known as the Daoseng ke 道僧科 (Rules for Daoists and Buddhists) of the year 637, and general legal codes, such as the Tang liudian 唐六典 (Six Departments of the Tang) and the Tang lü shuyi 唐律疏義 (Supplementary Interpretations of Tang Laws). The former, unfortunately, is lost but can be recovered partially from its Japanese counterpart, the Sōni ryō 僧尼律 (Regulations for Monks and Nuns), written also in the seventh century and representing the same basic outlook as the Chinese work (Ch'en 1973, p. 95).

According to these rules, ordained recluses were not supposed to ride horses, possess military books, form cliques, solicit guests, stay for more than three days among lay families, participate in musical or other entertainments, or behave in any way rudely or abusively to elders or those of higher rank (Ch'en 1973, pp. 102-103). Taking improper foods or liquor was punishable by hard labour; wearing silk clothes or aristocratic colours led to defrocking or hard labour; theft or desecration of sacred objects carried a punishment of prison, hard labour, or exile. Again, monks or nuns engaging in fortune telling and faith healing could be defrocked and, if they still continued their charlatanry, suffer strangulation. In general, all recluses had to be handed 
over to the secular authorities for serious crimes, especially robbery and murder (Ch'en 1973, pp. 96-102).

In exchange for financial and institutional support, the behaviour of all monastics was therefore closely circumscribed by the state. Moreover, the civil code punished offences more severely than the religious order, whether Buddhist or Daoist. For example, in cases where the vinaya ordered expulsion from the order, the state demanded extradition to secular justice and the death penalty; in situations where the vinaya demanded confessions, expiations, or rites of repentance, the state imposed imprisonment and hard labour (Ch'en 1973, pp. 97-98). More than that, the sources are quite explicit about the fact that the same offence was punished much more harshly in the case of a recluse than in that of a layman. The reason given is that the recluse should know what he was doing and, even worse, was harming or "stealing an object of his own religion" (Ch'en 1973, p. 100).

The Fengdao kejie does not mention mundane punishments for various infractions of the monastic rules, but relies entirely on supernatural justice, such as the law of karma and retribution and the reduction of life expectancy by the celestial administration (sects. 2-3; see Kohn 1998). Nevertheless, formal punishments were certainly in place and applied in practice - either by the monastic authorities or by their state supervisors. This assumption is supported by the Xuandu lüwen 玄都律 文 (Rules of Mystery Metropolis, DZ 188), a code for Celestial Master priests of the sixth century and a source of the Fengdao kejie, which adds demotion in rank to the standard subtraction of days from the lifespan. A citation from this text in the eighthcentury Yaoxiu keyi notes that Daoists who were punished or imprisoned by the civil authorities after their release had to undergo thirty days of purification and solitary repentance before they could attend any religious ceremonies (12.5b). Later Daoist codes, such as the rules governing the institutions of Complete Perfection, too, have detailed punishments, along the lines of the Buddhist vinaya. Measures include prostrations, demotion in rank, suspension of monastery privileges, expulsion from the order, and referral to the civil authorities (Yoshioka 1979, pp. 240-241).

Major Daoist monasteries of medieval China, therefore, needed a great deal of state or at least aristocratic support in order to set up and properly equip their establishments. Materials were rare and costly, labour was skilled and intense, and in general monks and nuns were relying to a large extent on outside funding and the goodwill of the state. In exchange, they catered to the benefit of their supporters, offering ritual services to the aristocrats and accepting a great degree of control from the state.

\section{Historical unfolding}

There are four major historical forerunners of the medieval Daoist monastery, each of which contributed significantly to the complex institution. They are:

- traditional Chinese architecture and city planning; these were responsible for the overall layout of the compound and the specific architectural design of its buildings; 
- the Buddhist monasteries of medieval China; they formed the basis for the distribution and specification of the various halls and buildings as well as for certain technical terms;

- the large communal assembly halls of the Celestial Masters; they were the forerunners of the sanctuary and other worship halls of the monastery;

- the personal hermitage of Daoist practitioners; this was first institutionalised as the chamber of tranquillity or “oratory” (jingshi 靜室), then developed into various separate buildings, towers, and terraces for individual practice.

Traditional Chinese architecture and city planning, then, had two major characteristics that were both shared by medieval Daoist monasteries. First, all building activity relied heavily on wood, not because stone was not available but because timber was easier to work and allowed a higher flexibility in design (Boyd 1962, p. 23; Liu 1989, p. 29). Generally, a coating of lacquer and a solid base of metal or stone would give wooden pillars an extended life while yet allowing frequent rebuilding and redesigning, as well as open spaces and flexible wall construction.

Typically all buildings consisted of a threefold structure: a base of beaten earth or stone, a frame made from timber, and a thatched or tiled roof (Boyd 1962, p. 25). The base was higher and multilayered for more important buildings, creating a ziggurat-like pattern, not unlike that of the altar platform used in Daoist ceremonies; the wooden pillars were protected from damp and termites by stone or metal bases while their tops were connected with each other and the roof by an intricate construction of blocks and bows, known as cantilevers (see Boyd 1962, pp. 30-31; Liu 1989, p. 30). This construction allowed maximum flexibility in both sizing the building and shaping the roof, supporting the curved roofline characteristic of Chinese architecture. Wall parts, moreover, were highly flexible, being basically screen elements that could be moved at will, permitting the creation of both an openness to the outside elements and of various enclosed spaces within (Boyd 1962, p. 34). ${ }^{20}$

The monastic buildings did not only follow the model of Chinese mainstream architecture in their design but also in their overall layout. Four distinct planning principles can be distinguished: axiality, a north-south orientation, walled enclosures, and courtyards (Boyd 1962, p. 49; Liu 1989, p. 33). Axiality, as mentioned earlier, meant the focus of the entire construction along a central axis, which moreover was typically laid out along a north-south line, with the main approach coming from the south and the more sacred or important buildings being toward the north. The entire complex, moreover, was surrounded by an enclosing wall, and it is thus no accident that the ancient word for "city" is the same as that for "wall" (cheng 成; Boyd 1962, p. 49). Not only a larger, surrounding wall on the outside, there were further enclosures within, each portion of the city being in itself an enclosed whole, separated from the next by an open space or courtyard.

Typically, a traditional city or palace would, therefore, be laid out on a central north-south axis and consist of the following: gate-courtyard-first hall-courtyard-

${ }^{20}$ A classic example of temple architecture based on these principles is the Foguangsi on Mt. Wutai, the oldest surviving wooden building in China, dated to 857. For pictures and sketches, see Boyd 1962, p. 34; Liu 1989, p. 92. 
middle hall-courtyard-inner hall (Boyd 1962, pp. 70-71). In each case, there would be many buildings, not merely one (Liu 1989, p. 27), the monumentality and symbolism of the construction lying in its entirety, not in the imposing nature or superb decoration of one single building (Boyd 1962, p. 73). Although laid out on one single axis, moreover, the city or palace were not completely open or allowed one straight vista. Rather, it undulated between open spaces, enclosed yards, and specific buildings, consisting of a succession of varied spaces in a related sequence (Boyd 1962, p. 73$)^{21}$

In the layout of religious complexes, which closely follows this mainstream scheme, the symbolism of the gradual increase and half-hidden movement is intensified, each step of the approach bringing the believer closer to the deity and/or teaching. The repetitiveness of the basic pattern (gate, arch, yard, building, backyard, wall), serves to create a rhythmicality of the cosmic movement, a punctuation in the graded approach to the saced (Liu 1989, p. 149). Thus, in the Yongle gong 永樂 宮 (Palace of Eternal Joy) in Shanxi, a major Daoist institution of the Yuan dynasty, there are four halls on a central axis: the gate, the Hall to the Three Pure Ones, the Hall to Patriarch Lü, and the Hall to Wang Chongyang 王重陽. ${ }^{22}$ Here the devotee approaches through the main gate - which is, moreover, marked by a series of other indicators, such as a sign, a landmark, or a lesser gate - then finds himself facing the Three Pure Ones, representations of the Dao. From there he moves on to the divine patriarch of the Complete Perfection school, whose revelation made the Dao accessible on earth, to then reach the hall of Wang Chongyang who founded the school and thus brought the teachings into this world.

Rather than moving ever farther away from the world and towards the Dao, the practitioner walking along the temple's axis thus comes closer to the actuality of the Dao in the world, transcending the secular world and yet also being in it - but in a more refined, more purely Daoist way. The entire complex, highly symbolic in layout and organisation, thus serves as a transitional environment that guides the believer from his ordinary self to a purer and more Daoist being. ${ }^{23}$ The same meaning can also be found in the layout of medieval monasteries, where believers first encounter the Sanctuary to the Three Pure Ones, then the Hall for Lecturing on the Scriptures. This allows them to relate first to the Dao in its divine form, then learn of its actuality as presented in the scriptures.

Whereas architecture and overall layout are determined by mainstream patterns, the specific nature, function, and naming of halls largely follows the Buddhist model. Thus, a classical Buddhist monastery would have a major sanctuary to the Buddha (dian 殿堂院), various halls for scripture study and meditation (tang 堂),

${ }^{21}$ Good examples in mainstream architecture are found in the Altar of Heaven in Beijing and the Confucius Hall in Qufu. See Boyd 1962, pp. 136-142.

${ }^{22}$ Described in Liu 1989, p. 133. For more on the Yongle gong, its layout and extensive frescoes, see White 1940; Katz 1993; 1994; 1997.

${ }^{23}$ For a discussion of the transitional nature of sacred space in China, see Liu 1989, p. 149; for an example of the approach to and structure of the Foguangsi, see Liu 1989, pp. 150-151. A study of sacred space as activated in the approach to Mt. Wudang, moreover, is found in Lagerwey 1992. 
a number of reclusive side buildings (yuan 院), a refectory (zhaitang 齋堂), as well as scripture tower (called jinglou 經樓) and many others more (Prip-Møller 1967, p. 36, p. 52, p. 92). The technical term for monastic servants, moreover, is jingren 淨人, lit. "pure people", and that for ordained visitors, shifang ke 十方客 or "guests of the ten directions" (Prip-Møller 1967, p. 98) - all terms shared by medieval Daoists.

In addition, similar to the Daoist structure, Buddhist institutions had first the Buddha Sanctuary, then the Scripture Hall, and then a Hall to the Thousand Buddhas, venerating all those released souls that went before and now serve as models to living practitioners (Prip-Møller 1967, p. 65). This reflects the Three Treasures of the religion, Buddha, Dharma, and Sangha, and - like the Yongle gong - guides the practitioner first to the goal of the religion, then to its teachings, and finally to its practice in the world. In addition, the Buddhist institution had a similar division into three circles of activities, with the central axis in the middle, the various practice facilities around it, and workshops and fields on the periphery (Prip-Møller 1967, p. 158), providing in arrangement and designation of buildings a feasible model for Daoist monasteries.

\section{Daoist precursors}

Two features of the Daoist monastic institution, moreover, can be traced to earlier Daoist buildings and halls: the large main hall with its statues and murals and intense ritual activity resembles in structure and function the communal assembly hall of the Celestial Masters, their so-called "parish centre" ( $z h i$ 治); and the outlaying buildings and pavilions for specific cultivation can be related to the chamber of tranquillity (jingshi 靜室) of the early schools, which in turn may be traced back to mountain hermitages of immortals of old.

Parish centres among the Celestial Masters were halls for the performance of communal rituals, where major purifications would be enacted, assemblies held, and petitions offered to the celestial administration for the pardoning of sins and the healing of diseases (Yoshikawa 1987, pp. 137-140). They were simple wooden structures, built in traditional style on a foundation of tamped earth and covered by thatched roofs, originally no more than twenty square metres in size, which by the fifth century, in the time of Lu Xiujing, had grown to many times this (Bumbacher 1996, pp. 509-510). They were built on an east-west axis, with incense offered in both directions and the main worship begun by facing east. A large table-style altar would be in the centre, containing talismans and other signs of the deities as well as writing utensils for the making-out of petitions. Later, statues and paintings (murals, scrolls) were added, and the rites became more extensive and elaborate (Yoshikawa 1987, pp. 135-136).

The chamber of tranquillity was a smaller and older version of the parish centre, and some scholars even suspect that the centre derived from the chamber (Yoshikawa 
1987 , p. 131). ${ }^{24}$ It consisted of a single detached building anywhere from ten to twenty square metres in size, covered by a thatched roof, surrounded by running water, and protected by a wall (Yoshikawa 1987, p. 129). Unlike the parish centre, it was to be erected well away from human noise and habitation and had to be kept in strict simplicity without any ornamentation. Even the numbers of wooden supports should be limited to four pillars, three rafters, and two beams, and they should all be made from the same simple, local wood, not from a variety of fancy timbers to be imported over large distances (Yoshikawa 1987, p. 129). It should have windows to allow a maximum control of wind and light and a screen-door entrance that could be easily moved. A wooden bench should be placed in the centre, according to one measurement given, approximately $2.5 \times 1.9$ metres in floor size and 31 centimetres high (Zhen'gao 18); Yoshikawa 1987, p. 129). In addition, the chamber was to contain only four things: an incense burner, incense lamp, table for petitions, and writing knife (Yoshikawa 1987, p. 128; Bumbacher 1996, p. 507). It could only be entered after extensive purification and all actions within it must be accompanied by a great deal of ritual formality (Yoshikawa 1987, pp. 140-144).

The chamber is named variously in the literature as the chamber of tranquillity (jing 靜), peace (jing 靖), concentration (jing 精), purity (jing 淨), or clarity (qing 清), or sometimes simply as "chamber of the Dao" (daoshi 道室; Yoshikawa 1987, p. 125). It had four distinct functions in early medieval Daoism, being first a mountain hermitage of immortals who wished to dedicate themselves entirely to the Dao; next, a concoction chamber for alchemical elixirs, similarly erected in a remote mountain area by someone solely aspiring for Daoist release ${ }^{25}$ third, a place for prayer and repentance among the Celestial Masters, here established in imitation of the punishment hut used in Han-dynasty officialdom; and fourth, a hut of retreat and study for aristocrats, set up in a far corner of their estates (Yoshikawa 1987, p. 126). In all cases, the key function of the chamber was self-cultivation, providing a place of retreat and tranquillity where the inner self could be confronted and developed. ${ }^{26}$

As such it is in many ways similar to the hermitages or meditation huts used by Buddhists, which too consisted of a simple room for devotion that contained only an altar and a meditation cushion, and maybe a simple bed and desk. Like their Daoist counterparts, they were erected as separate buildings and enclosed by a wall, located away from towns, estates, or even larger monasteries. Being highly sacred in function, they had to be specially erected and dedicated and could only be used after proper consecration and the undergoing of formal purifications (Prip-Møller 1967, p. 152). What is more, in the Buddhist case, the subtemples (yuan) of the larger monastic compounds have been clearly traced to these meditation huts, which moreover

${ }^{24}$ Sources on the chamber include Daolei shixiang, 4.1a-6b; Daomen kelue 道門科略 (DZ 1127; trl. Nickerson 1996); Xuandu lüwen; and Zhen'gao 真誥 (DZ 1016), ch. 18. Among Western studies, see especially Eichhorn 1954; Chen 1975, pp. 330-351; Stein 1963, p. 38; Bumbacher 1996, pp. 504-508; Yoshikawa 1987.

${ }^{25}$ In this sense, the jingshi is like the danfang 丹房 (elixir chamber) of the alchemists. It is linked to this chamber, both on the worldly and celestial plane, in the Daolei shixiang 2.4b.

${ }^{26}$ A similar function can also be observed in the case of various fang or chambers among the Celestial Masters. See Daolei shixiang 2.4a. 
were often also grottoes located on extended monastic grounds (Prip-Møller 1967, p. 72). It is thus a reasonable assumption to link the chambers of tranquillity with the various buildings for personal cultivation that formed an important part of the medieval Daoist monastery.

Generally considering the historical unfolding of the medieval Daoist institution, I would argue that it began with the most basic chamber of tranquillity, i.e., the personal hermitage or meditation hut of immortality seekers, which then grew first into the repentance and prayer room of the Celestial Masters and the elixir chamber of alchemical practitioners, then, by the fifth century, became a formal Daoist place of retreat. Joined together with the parish halls for large assemblies, which were first developed among the Celestial Masters, these chambers formed the backbone of the fully developed monastery - the more public and communal buildings in the centre, the more personal and individual hermitages on the periphery. The entire complex was then, following traditional Chinese architecture and city planning, built in mainstream temple style and laid out along a central axis. Specific designations of various buildings, together with their technical nomenclature, finally, were adopted from the Buddhist institution flourishing around the same time.

\section{Conclusion}

Medieval Daoist monasteries were communal institutions comparable to Buddhist and medieval Christian centres. They housed monks and nuns in various numbers, came in different forms and sizes, and are often shrouded in mystery. Only the larger, public teaching institutions, whose description has come down to us especially in the Fengdao kejie of the early Tang dynasty, can be analysed in some detail. Architecturally consisting of about thirty different buildings, they were located on mountainsides but not too far from administrative centres, built with no expenses spared, and supported largely by the imperial court and/or aristocratic patrons. Their layout and structure can be described in three concentric circles, a holy centre laid out on a central axis, a ring of practice and support around it, which was yet enclosed by a wider area of economic activity, including fields, orchards, oil presses, mills, and the like. In terms of style and layout, they followed the mainstream models of traditional China, reflecting the principles of ancient palace architecture and city planning. While, moreover, the specific buildings chosen and their technical designations derived to a large extent from Buddhist models, the two most basic components of the monastery - halls for communal worship and separate buildings for personal practice - can be traced back to ancient Daoist institutions, the parish centre and the chamber of tranquillity.

All this holds true for the Daoist monastery in the Tang dynasty, as it evolved from hermitages through local centres or hostels in the fifth and sixth centuries. Flourishing throughout the Tang, the monastery later came to serve as the basis for institutions of the Complete Perfection school, which integrates the Song model of Buddhist Chan monasteries and can still be seen today. Yoshioka Yoshitoyo de- 
scribes the institution on the basis of an extended stay at Beijing's Baiyun guan (White Cloud Monastery) in 1940, the fundamental structure is still the same: a series of buildings and courtyards along a central north-south axis, surrounded on both sides by various support divisions (Yoshioka 1979, p. 250). The buildings have become more numerous, growing to include several gates and a series of halls, including also one to the Jade Emperor and to Patriarch Qiu. In addition, the Sanctuary of the Three Pure Ones is located farther toward the back of the compound, not in its beginning, and is followed by an ordination platform or open-air altar, which too was placed further up front in the medieval model (Yoshioka 1979, p. 251; see also Hachiya 1990). This is different from the Song Buddhist arrangement, which still follows the earlier pattern, setting out halls to Buddha, Dharma, and Sangha in this order (Foulk 1993, p. 169), but may reflect a reorientation of the Daoist community.

Similar to Song Buddhist patterns, however, and unlike the earlier medieval monastery, the Complete Perfection complex arranges the support buildings in four groups along the central axis: first the refectory, kitchen, and burial pagodas are found on the left towards the upper end, facing shrine halls to various individual patriarchs and the earth god on the right; then several lesser cultivation halls, ancestral shrines, and guest quarters for itinerant monks are located on the left towards the lower end of the compound, facing the outhouses, pigsties, sheep pens, business rooms, workshops and public monks' hall on the right (Yoshioka 1979, pp. 250-251). This arrangement mirrors Song and Japanese Chan institutions and reflects a thinking that associates the parts of the monastery with different sections of the human body: the central axis with the main buildings being the torso, the upper support division being the arms and hands, and the lower support section serving as the legs and feet. Having less land and agricultural facilities than its medieval forerunner, the head monastery of Complete Perfection today is thus no longer arranged in three concentric circles (or even two) but places all the different buildings and activities right along the central axis, using an anthropomorphic image as its model.

Another major difference between the medieval and the later Daoist monastery is the structure of monastic administration and offices. The Fengdao kejie does not mention any offices or administrative roles at all, limiting itself to a detailed outline of ordination ranks and hierarchy. Possibly within any given centre certain administrative duties were linked with certain specific ranks, but if so the texts keep silent about them. In the Yuan dynasty and today, on the other hand, there are numerous administrative functions, many of which resemble those used in Buddhist institutions but whose nomenclature is significantly different. ${ }^{27}$ Still, despite this lacuna in our information, we can say that the medieval Daoist monastery was a major institution of traditional China, encompassing and developing certain key elements of mainstream and Buddhist culture - and showing remarkable similarity with medieval Christian institutions - whose influence has remained active until the present day.

\footnotetext{
${ }^{27}$ On the Daoist roles and titles Thomas H. Hahn gave a revealing presentation, "Ritualisation of the Other: Chinese Taoist Monasteries and Their Ways of Embracing Guests," at the 50th Annual Meeting of the Association for Asian Studies, Washington, D.C., March 1998. For an overview of Buddhist monastic administration, see Welch 1967.
} 


\section{References}

Akizuki Kan'ei 秋月觀英 (1964): Rikuchō dōkyō ni okeru ōhōsetsu no hatten 六朝道教 に打ける應報説の發展. Hirosaki daigaku jimbun shakai 弘前大學人文社 會 33, pp. 25-60.

Akizuki Kan'ei (1965): Sairon sangen shisō no keisei 再論三元思想の形成. Hirosaki daigaku bunkyō ronsō 弘前大學 文經論丵 1, pp. 437-456.

Benn, Charles D. (1991): The Cavern Mystery Transmission: A Taoist Ordination Rite of A.D. 711. Honolulu, University of Hawaii Press.

Bilsky, Lester J. (1975): The State Religion of Ancient China. 2 vols. Taipei, Chinese Folklore Association.

Boyd, Andrew (1962): Chinese Architecture and Town Planning. London, Alec Tiranti.

Bumbacher, Stephan Peter (1996): The Fragments of the Daoxue zhuan: Critical Edition, Translation and Analysis of a Medieval Collection of Daoist Biographies. Ph.D. dissertation, Tübingen University.

Burton, Janet (1994): Monastic and Religious Orders in Britain, 1000-1300. Cambridge, Cambridge University Press.

Chang Kuang-chih (1976): Early Chinese Civilization: Anthropological Perspectives. Cambridge, Mass., Harvard-Yenching Institute Monograph Series 23.

Chen Guofu 陳國符 (1975): Daozang yuanliu kao 道藏源流考. Taipei, Guting.

Ch'en, Kenneth (1973): The Chinese Transformation of Buddhism. Princeton, Princeton University Press.

Covell, Jon (1974): Zen at Daitokuji. Tokyo, Kōdansha International.

De Groot, J. J. M. (1903): Sectarianism and Religious Persecution in China. Amsterdam, Johannes Müller.

De Groot, J. J. M. (1969) [1893]: Le Code du Mahāyāna en Chine: Son influence sur la vie monacale et sur le monde laïque. Wiesbaden, Dr. Martin Sändig.

Ding Huang 丁煌 (1979): Tangdai daojiao taiqing gong zhidu kao 唐代道教太清宮制度 考. Part I. Lishi xuebao 歷史學報 (Chenggong University) 6, pp. 275-314.

Doub, William C. (1971): A Taoist Adept's Quest for Immortality: A Preliminary Study of the Chou-shih Ming-t'ung chi by T'ao Hung-ching. Ph.D. Dissertation, University of Washington, Seattle.

Dutt, Sukumar (1962): Buddhist Monks and Monasteries of India: Their History and Contribution to Indian Culture. London, Allen and Unwin.

Eichhorn, Werner (1954): Description of the Rebellion of Sun En and Earlier Taoist Rebellions. Mitteilungen des Instituts für Orientforschung 2.2, pp. 325-352 and 2.3, pp. 463-476.

Forte, Antonino (1992): Chinese State Monasteries in the Seventh and Eighth Centuries. In: E Cho $\bar{O}$ Gotenchikukuo den kenkyu 慧超往五天筑國傳研究, edited by Kuwayama Seishin 桑山正進, pp. 213-58. Kyoto, Kyoto University, Jimbun kagaku kenkyūjo.

Foulk, T. Griffith (1987): The 'Ch'an School' and Its Place in the Buddhist Monastic Tradition. Ph.D. dissertation, Ann Arbor, University of Michigan.

Foulk, T. Griffith (1993): Myth, Ritual, and Monastic Practice in Sung Ch'an Buddhism. In: Religion and Society in T'ang and Sung China, pp. 147-208. Edited by P. B. Ebrey and P. N. Gregory. Honolulu, University of Hawaii Press.

Funayama Tōru 船山撤 (1998): Tō Hōkei to bukkyō no kairitsu 陶弘景の佛教と戒律. In: Rikuchō dōkyō no kenkyū 六朝道教の研究, edited by Yoshikawa Tadao 吉川 忠夫, pp. 353-376. Kyoto, Shunjūsha. 
Gernet, Jacques (1995): Buddhism in Chinese Society: An Economic History from the Fifth to the Tenth Centuries. Translated by Franciscus Verellen. New York, Columbia University Press.

Hachiya Kunio 蜂屋國夫 (1990): Chūgoku dōkyō no genjō: Dōshi, dōkyō, dōkan 中國道教 の現壯 - 道士道協道觀. 2 vols. Tokyo, Tokyo daigaku Tōyō bunka kenkyūjo.

Hackmann, Heinrich (1920): Die Mönchsregeln des Klostertaoismus. Ostasiatische Zeitschrift 8, pp. 141-170.

Hillery, George A. (1992): The Monastery: A Study in Love, Freedom, and Community. Westport, CT, Praeger.

Horn, Walter - Born, Ernest (1979): The Plan of St. Gall: A Study of the Architecture and Economy of, and Life in, a Paradigmatic Carolingian Monastery. 3 vols. Berkeley, University of California Press.

Katz, Paul R. (1993): The Religious Function of Temple Murals in Imperial China: The Case of the Yung-lo Kung. Journal of Chinese Religions 21, pp. 45-68.

Katz, Paul R. (1994): The Interaction Between Ch'üan-chen Taoism and Local Cults: A Case Study of the Yung-lo Kung. In: Proceedings of the International Conference on Popular Beliefs and Chinese Culture. Taipei, Center for Chinese Studies, pp. 201-250.

Katz, Paul R. (1997): Temple Inscriptions and the Study of Taoist Cults: A Case Study of Inscriptions at the Palace of Eternal Joy. Taoist Resources 7.1, pp. 1-22.

Kingsley, Karen (1987): Monastery. In: Enclyclopedia of Religion, edited by Mircea Eliade, 10, pp. 30-35. New York, Macmillan.

Kobayashi Masayoshi 小林正美 (1990): Rikuchō dōkyōshi kenkyū 六朝道教史研究. Tokyo: Sōbunsha.

Kohn, Livia (1995): Laughing at the Tao: Debates among Buddhists and Taoists in Medieval China. Princeton, Princeton University Press.

Kohn, Livia (1997a): The First Handbook of Monastic Daoism: The Date and Compilation of the Fengdao kejie. East Asian History 13/14, pp. 91-118.

Kohn, Livia (1997b): Yin Xi: The Master at the Beginning of the Scripture. Journal of Chinese Religions 25, pp. 83-139.

Kohn, Livia (1998): Steal Holy Food and Come Back as a Viper: Conceptions of Karma and Rebirth in Medieval Daoism. Early Medieval China 4, pp. 1-48.

Kroll, Paul W. (1985): In the Halls of the Azure Lad. Journal of the American Oriental Society 105, pp. 75-94.

Lagerwey, John (1987): Taoist Ritual in Chinese Society and History. New York, Macmillan.

Lagerwey, John (1992): The Pilgrimage to Wu-tang Shan. In: Pilgrims and Sacred Sites in China, edited by Susan Naquin and Chün-fang Yü, pp. 293-332. Berkeley, University of California Press.

Liu, Laurence (1989): Chinese Architecture. New York, Rioli.

Liu Tsun-yan 柳存仁 (1986): Sandong fengdao kejie yifan juan diwu: P. 2337 zhong Jin Ming Qizhen yici zhi tuice 三洞奉道科戒儀籁卷第五 P 。2337 中金明七真遺 册之推測. Hanxue yanjiu 漢學研究 4.2, pp. 509-531.

Mather, Richard B. (1979): K'ou Ch'ien-chih and the Taoist Theocracy at the Northern Wei Court 425-451. In: Facets of Taoism, edited by Holmes Welch and Anna Seidel, pp. 103-122. New Haven, Conn., Yale University Press.

Mather, Richard B. (1981): The Bonze's Begging Bowl: Eating Practices in Buddhist Monasteries of Medieval India and China. Journal of the American Oriental Society 101, pp. 417-423.

Nickerson, Peter (1996): Abridged Codes of Master Lu for the Daoist Community. In: Religions of China in Practice, edited by Donald S. Lopez Jr., pp. 347-359. Princeton, Princeton University Press. 
Ōfuchi Ninji 大淵忍爾 (1979): Tonkō dōkei: Zuroku hen 敦煌道經圖錄篇. Tokyo, Kokubu shoten.

Ōfuchi Ninji (1997): Dōkyō to sono kyōten 道教とその經典. Tokyo, Sōbunsha.

Ozaki Masaharu (1986): The Taoist Priesthood: From Tsai-chia to Ch'u-chia. In: Religion and Family in East Asia, edited by G. DeVos and T. Sofue, pp. 97-109. Berkeley, University of California Press.

Pas, Julian F. (1987): Six Daily Periods of Worship: Symbolic Meaning in Buddhist Liturgy and Eschatology. Monumenta Serica 37, pp. 49-82.

Porter, Bill (1993): The Road to Heaven: Encounters with Chinese Hermits. San Francisco, Mercury House.

Prebish, Charles S. (1975): Buddhist Monastic Discipline: The Sanskrit Pratimoksha Sutras of the Mahasamghikas and Mulasarvastivadins. University Park, PA, The Pennsylvania State University Press.

Prip-Møller, J. (1967): Chinese Buddhist Monasteries. Hongkong, Hongkong University Press.

Reiter, Florian C. (1983): Some Observations Concerning Taoist Foundations in Traditional China. Zeitschrift der deutschen morgenländischen Gesellschaft 133, pp. 363-76.

Reiter, Florian C. (1988): The Visible Divinity: The Sacred Image in Religious Taoism. Nachrichten der deutschen Gesellschaft für Natur- und Völkerkunde Ostasiens 144, pp. 51-70.

Reiter, Florian C. (1992): Kategorien und Realien im Shang-ch'ing Taoismus (Shang-ch'ing taolei shih-hsiang): Arbeitsmaterialien zum Taoismus der frühen T'ang-Zeit. Wiesbaden, Harrassowitz.

Reiter, Florian C. (1998): The Aspirations and Standards of Taoist Priests in the Early T'ang Period. Wiesbaden, Harrassowitz.

Ren Jiyu 任繼俞 - Zhong Zhaopeng 鐘肇鵬 (eds) (1991): Daozang tiyao 道藏提要. Beijing, Zhongguo shehui kexue chubanshe.

Robinet, Isabelle (1989): Visualization and Ecstatic Flight in Shangqing Taoism. In: Taoist Meditation and Longevity Techniques, edited by Livia Kohn, pp. 157-90. Ann Arbor, University of Michigan, Center for Chinese Studies Publications.

Schafer, Edward H. (1977): Pacing the Void. Berkeley, University of California Press.

Schafer, Edward H. (1980): Mao-shan in T'ang Times. Boulder, Col., Society for the Study of Chinese Religions Monograph 1.

Schipper, Kristofer (1975): Concordance du Tao Tsang: Titres des ouvrages. Paris, Publications de l'Ecole Française d'Extrême-Orient.

Schipper, Kristofer (1984): Le monachisme taoïste. In: Incontro di religioni in Asia tra il terzo e il decimo secolo $d$. C., edited by L. Lanciotti, pp. 199-215. Firenze, Leo S. Olschki.

Soothill, William E. (1952): The Hall of Light: A Study of Early Chinese Kingship. New York, Philosophical Library.

Soothill, William E.-Hudous, Lewis (1937): A Dictionary of Chinese Buddhist Terms. London, Kegan Paul.

Stein, Rolf A. (1963): Remarques sur les mouvements du taoïsme politico-religieux au $\mathrm{II}^{\mathrm{e}}$ siècle ap. J.-C. T'oung-pao 50, pp. 1-78.

Strickmann, Michel (1978): A Taoist Confirmation of Liang Wu-ti's Suppression of Taoism. Journal of the American Oriental Society 98, pp. 467-474.

Strickmann, Michel (1979): On the Alchemy of T'ao Hung-ching. In: Facets of Taoism, edited by Holmes Welch and Anna Seidel, pp. 123-192. New Haven, Conn., Yale University Press.

Tonkō kōza 敦煌講座 (1983): Tonkō to hūgoku dōkyō 敦煌と中 國道教. Tokyo, Daitō.

Turner, Victor W. (1969): The Ritual Process: Structure and Anti-Structure. Chicago, Aldine. 
Twitchett, Dennis W. (1956): Monastic Estates in T'ang China. Asia Major, New Series, 5, pp. 123-146.

Twitchett, Dennis W. (1957): The Monasteries and China's Economy in Mediaeval China. Bulletin of the School of Oriental and African Studies 19, pp. 526-549.

Wang, Yi-t'ung (1984): A Record of Buddhist Monasteries in Lo-yang. Princeton, Princeton University Press.

Weckman, George (1987): Monasticism: An Overview. In: Encyclopedia of Religion, edited by Mircea Eliade, 10, pp. 35-41. New York, Macmillan.

Welch, Holmes (1967): The Practice of Chinese Buddhism, 1900-1950. Cambridge, Mass., Harvard University Press.

White, William Charles (1940): Chinese Temple Frescoes: A Study of Three Wall-Paintings of the Thirteenth Century. Toronto, University of Toronto Press.

Wijayaratna, Mohan (1990): Buddhist Monastic Life. Cambridge, Cambridge University Press.

Wright, Arthur F. (1951): Fu I and the Rejection of Buddhism. Journal of the History of Ideas 12, pp. 33-47.

Wright, Arthur F. (1990): Studies in Chinese Buddhism. Edited by Robert Somers. New Haven, Conn., Yale University Press.

Yao Tao-chung (1980): Ch'üan-chen: A New Taoist Sect in North China During the Twelfth and Thirteenth Centuries. Ph.D. dissertation, Phoenix, University of Arizona.

Yoshikawa Tadao 吉川忠夫 (1984): Rikuchō seishinshi kenkyū 六朝精神史研究. Kyoto, Hōyūsha.

Yoshikawa Tadao (1987): Seishitsu kō 靜室考. Tōhō gakuhō 束方學報 59, pp. 125-162.

Yoshioka Yoshitoyo 吉岡義豐 (1955): Dōkyō kyōten shiron 道教經典史論. Tokyo, Dōkyō kankōkai.

Yoshioka Yoshitoyo (1976): Dōkyō to bukkyō 道教と佛教, vol. 3. Tokyo, Kokusho kankōkai.

Yoshioka Yoshitoyo (1979): Taoist Monastic Life. In: Facets of Taoism, edited by Holmes Welch and Anna Seidel, pp. 220-252. New Haven, Conn., Yale University Press.

Zito, Angela (1997): Of Body and Brush: Grand Sacrifice as Text/Performance in EighteenthCentury China. Chicago, University of Chicago Press. 